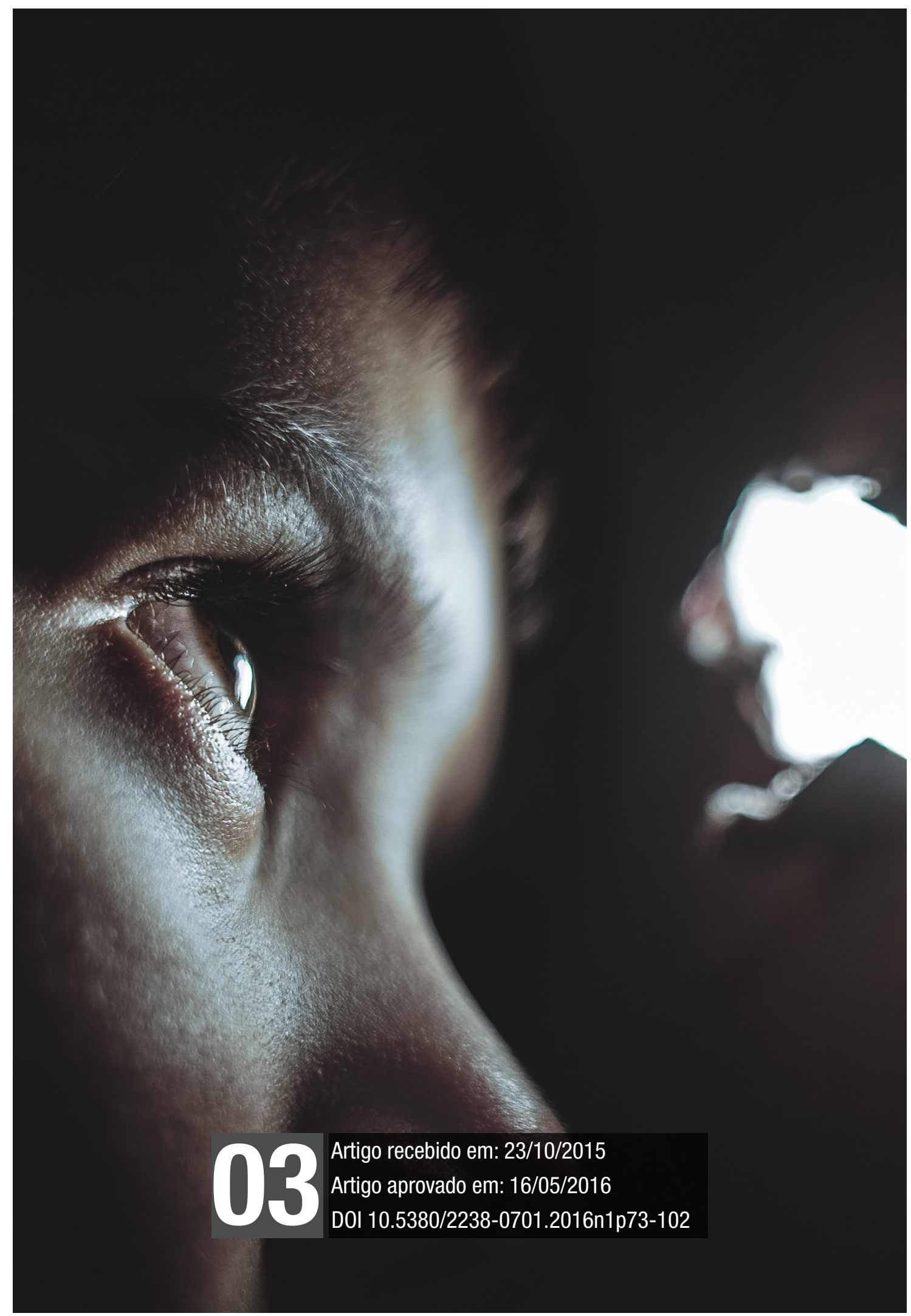


Medo. Mídia. Imaginário. Repercussão.

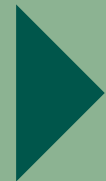




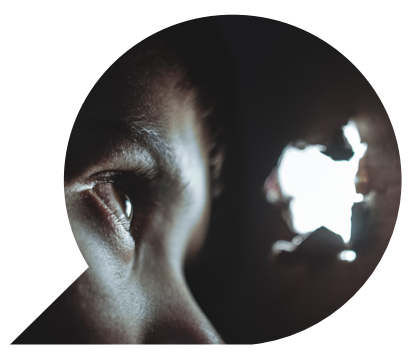

\section{Insegurança e medo: exageros midiáticos? ${ }^{\star}$}

Insecurity and fear: amplified media?

La inseguridad y el miedo: exageración de los medios?

\section{MÔNICA CRISTINE FORT *}

Resumo: $\mathrm{O}$ artigo aborda o medo provocado e amplificado pela mídia. Trata a relação sujeito-mídia involuntária e compulsória, por meio da qual cenários ficam ainda mais dramáticos em determinadas circunstâncias. Apresenta situações que podem levar ao temor exagerado quanto à preservação do corpo, da propriedade, da ordem social; um medo derivado, facilmente desacoplado de ameaças e perigos que os causam. Na perspectiva de ethos discursivo, discute notícias de veículos impressos e digitais que da seleção de pautas à elaboração de títulos provocam angústias e frustrações.

Palavras-chave: Medo; Mídia; Imaginário; Repercussão.

\footnotetext{
* Versão parcial e preliminar do presente texto foi apresentada pela autora no XXXVIII Congresso Brasileiro de Ciências da Comunicação, Rio de Janeiro, 4 a 7 de setembro de 2015.

${ }^{* *}$ Doutora em Engenharia da Produção pela Universidade Federal de Santa Catarina (UFSC). Pós-doutora em Comunicação pela Universidade do Estado do Rio de Janeiro (UERJ). Professora e pesquisadora vinculada ao Programa de Pós-Graduação em Comunicação e Linguagens da Universidade Tuiuti do Paraná (PPGCom/UTP). Vice-líder do Grupo de Pesquisa Interações Comunicacionais, Imagens e Culturas Digitais - INCOM/CNPq. E-mail: monica.fort@yahoo.com.br
} 


\begin{abstract}
The article discusses the fear caused and amplified by the media. The subject-media relationship is involuntary, however, compulsory. In this way, scenarios are even more dramatic in certain circumstances. The text presents situations that can lead to exaggerated fears about the preservation of the body, property, social order; it is a fear derived easily uncoupled from the threats and dangers that cause. From the perspective of discursive ethos, printed and digital news are discussed because from the selection of guidelines to the preparation of titles these can provoke anxieties and frustrations.
\end{abstract}

Keywords: Fear; Media; Imaginary; Repercussion.

Resumen: Este artículo aborda el miedo provocado y amplificado por los medios de comunicación. A través de la relación sujeto-media involuntaria, sin embargo, obligatoria, los escenarios se quedan aún más dramáticos en ciertas circunstancias. El texto presenta situaciones que pueden conducir a temores exagerados acerca de la conservación del cuerpo, de la propiedad, del orden social, el miedo derivado, que es fácilmente desenganchado de las amenazas y peligros que los causan. Desde la perspectiva del ethos discursivo, discute noticias de medios impresos y digitales que desde el principio hasta el final de la producción de noticias provocan ansiedades y frustraciones.

Palabras clave: Miedo; Medios de Comunicación; Imaginario; Repercusión. 


\section{Introdução}

A quantidade de informações que recebemos diariamente cria uma nova forma de medo, mais evasiva e abstrata (AUGÉ, 2013). É difícil de combatê-la, afinal é impalpável e imaterial, é uma angústia provocada por situações que assustam, sem necessariamente, estarem próximas. Os índices de violência urbana, por exemplo, são retratados (exemplificados) por reportagens de crimes cotidianos diversos; mudanças climáticas, evidenciadas por secas ou inundações e ainda por ondas de frio ou calor excessivo (fora de época); epidemias e doenças novas ou já conhecidas, mas que estão cada vez mais difíceis de se combater. A imprensa reporta esses fatos, pois é necessário informar a sociedade. Faz parte de suas rotinas produtivas: coletar, apurar, selecionar, editar e divulgar conteúdos que sejam relevantes e de interesse público. $\mathrm{O}$ que diz respeito a determinadas pessoas, acaba, contudo, uma hora ou outra, envolvendo todo o auditório. Catástrofes nucleares, epidemias, terrorismo, ameaças do sistema financeiro assumem características quase apocalípticas. E esse tom dramático chega a provocar horror. Zygmunt Bauman (2008) se refere à liquidez do medo, um medo derivado; Barry Glassner (2003), a uma cultura do medo; Marc Augé (2013), novos medos amplificados pela mídia.

Luzia Fátima Baierl (2008), no artigo Medo social: dilemas cotidianos, relata pesquisa que procurou identificar os medos sociais vividos no cotidiano como resultantes da forma como a violência urbana se expressa e se manifesta na atualidade. A autora comenta o chamado medo cíclico, identificado em entrevistas realizadas com cidadãos de classe média quando dizem deixar de frequentar determinados locais por esses parecerem ameaçadores.

[...] motivado por situações reais conhecidas, principalmente através da mídia ou pela fala cotidiana do crime, independente da possibilidade real dele vir acontecer ou de ter sido vivenciado diretamente pela pessoa, familiares ou vizinhança. Trata-se de um medo imaginário... (BAIERL, 2008, p. 143).

A intenção do presente artigo é discutir a insegurança e o medo provocados pelo conhecimento, adquirido por meio de notícias cotidianas, de situações que nem sempre são próximas, nem sempre são letais, nem sempre são ameaças reais. A partir de títulos de notícias divulgadas pelo Brasil Post e pelo jornal O Estado de S. Paulo, visa de- 
monstrar como a imprensa, ao reportar determinados conteúdos com frequência, dependendo dos episódios sociais de apelo e interesses populares, amplifica a sensação de insegurança. Leva em consideração pressupostos de Maingueneau (1993, 2013, 2014, 2015), a quem todo discurso mantém relação essencial com elementos pré-construídos, produzidos em outros discursos, anteriores a ele, independentes dele. Pelo princípio do interdiscurso, o jornalismo legitima informações e, assim, amplifica suas causas e consequências. São três domínios de interdiscurso: o da memória, o da atualidade e o da antecipação.

A proposta, ora apresentada, associa o medo relacionado ao número de casos de dengue registrado em cidades que enfrentaram crise hídrica em 2014-2015. Quem acompanhava as notícias sobre a doença, percebia que o número de casos havia praticamente dobrado de um mês para outro. Na comparação com o ano anterior, a situação era ainda pior. A dengue estava mais ameaçadora, "de verdade" e, ao indicar essa comparação (associar o número de casos com o mesmo período um ano antes) apresenta o domínio da memória. Ao mesmo tempo, predomina a atualidade, afinal são fatos recentes reportados (“este ano", em 2015). O domínio da antecipação está presente também: providências devem ser tomadas senão a situação vai se agravar, pelo menos é o que se espera ao reportar um cenário que exige mudanças ou interferência social e política.

\section{Realidade ou exagero?}

Em A crise no castelo da cultura, Moisés de Lemos Martins discute a ideia da verdade. $\mathrm{O}$ autor apresenta o tema sob diferentes paradigmas. Para Martins (2011, p. 39), um "debate sobre a verdade não pode ser outra coisa que um debate sobre a natureza e o estatuto do nosso conhecimento". Independentemente dos debates acerca do conceito de verdade, destaca-se a referência que o autor faz à crítica da metafísica de Nietzsche: “... princípio, que prevaleceu de Platão a Schopenhauer, segundo o qual pensar é para os homens descobrir o fundamento que lhes permita falar de acordo com o verdadeiro e agir de acordo com o bem e com o justo" (MARTINS, 1994, p. 6). Assim, por mais que o público receptor possa desconfiar do veículo que transmite determinada informação, pressupõe que os relatos de fatos sejam verdadeiros.

Na pós-modernidade, os sujeitos são vítimas de sobrecarga informacional. E o bombardeio de informações que recebem faz com que 
a relação sujeito-mídia seja involuntária e compulsória (MATUCK, 2000). Mesmo sem querer, recebe-se uma série de informações, tanto por veículos impressos como por eletrônicos e digitais. Além disso, há os compartilhamentos nas redes sociais realizados por leitores ávidos em comentar, criticar ou apenas repercutir determinados conteúdos. Entre as informações de caráter jornalístico, por exemplo, há notícias que aproximam os receptores de ameaças e provocam medo. Bauman (2008, p. 10) comenta que há três tipos de perigos: os que "ameaçam o corpo e as propriedades"; os que ameaçam "a durabilidade da ordem social e a confiabilidade nela" (exemplos: renda, emprego, sobrevivência, velhice); e os que "ameaçam o lugar da pessoa no mundo" (posição na hierarquia social, identidade - de classe, gênero, étnica, religiosa -, e "a imunidade à degradação e à exclusão sociais"). Esses perigos possuem apelo noticioso, portanto frequentemente se encontram reportagens a respeito de eventos que ameaçam a sociedade.

Mas numerosos estudos mostram que, nas consciências dos sofredores, o "medo derivado" é facilmente "desacoplado" dos perigos que os causam. As pessoas às quais ele aflige com o sentimento de insegurança e vulnerabilidade podem interpretá-lo com base em qualquer dos três tipos de perigos - independentemente das (e frequentemente em desafio às) evidências de contribuição e responsabilidade relativas a cada um deles (BAUMAN, 2008, p. 10).

O antropólogo francês Marc Augé (2013), em Les Nouvelles Peu$r s$, afirma que vivemos em uma realidade que, não raro, é reduzida a um emaranhado confuso de medos. O autor faz referências aos medos socioeconômicos, aos medos provocados por ações político -ideológicas, às mudanças climáticas e, consequentemente, ambientais, às ameaças criminosas. Para Augé, essas situações se sobrepõem e se confundem, amplificando-se mutuamente, produzindo pânico e provocando angústia nos indivíduos. Portanto, se há uma situação presente na realidade concreta das sociedades líquidas é o medo: de perder o emprego, da violência urbana, do terrorismo, de chuva em excesso, da falta de chuva, da falta de amor, da solidão... E o medo de ficar gordo(a), feio(a), excluído(a)... O medo de contrair doenças, de colocar a saúde em risco... É um medo provocado pela dimensão da informação em tempo real.

A mídia apresenta ao mundo diariamente, e de maneira contínua, uma narrativa. Sua função é ajudar a entender os relatos de 
experiências, com atores principais e "coadjuvantes". Causa identificação, empatia. Os fatos, algumas ameaças e alguns perigos, estão próximos, parecem palpáveis.

O medo induzido pela mídia pode muitas vezes ser intenso e durar longos períodos. Nem sempre é fácil prever qual conteúdo será perturbador. Ao avaliar o provável nível dos danos causados pelo conteúdo assustador, é preciso distinguir os tipos de conteúdo (p. ex., ameaça física ou psicológica), grau de realismo, motivação para "exposição", além de variáveis de receptor relacionadas a personalidade, idade e estabilidade emocional (McQUAIL, 2013, p. 454).

As fontes de informação precisam ter credibilidade para que os leitores ${ }^{1}$ sintam-se esclarecidos. E os compartilhamentos são praticamente instantâneos, ou seja, a notícia é publicada e já está sendo replicada. Nas redes sociais, o recorte sai do todo e passa a ser conhecido por quem segue aquele determinado leitor, por quem acredita, confia nele ou, simplesmente, simpatiza com ele. Não são poucos os relatos de notícias que tiveram repercussão nas redes sociais, mas que eram anúncios publicitários, factoides ou piadas de sites de humor. O formato era de conteúdo noticioso, assim despertava credibilidade - embora se questione esse "crédito" dado por falta de interpretação.

Maingueneau (1993, p. 49) afirma que os coenunciadores, os destinatários de um discurso, são também alguém que tem “acesso ao 'dito' através de uma 'maneira de dizer' que está enraizada em uma 'maneira de ser', imaginário de um vivido”. Assim, entende-se que a imprensa, por exemplo, convence seus leitores (coenunciadores) ao "atestar o que é dito na própria enunciação, permitindo a identificação com uma certa determinação do corpo" (MAINGUENEAU, 1993). A persuasão, o convencimento, acaba acontecendo pela própria formação dos textos jornalísticos transmitidos. Dado o princípio da veracidade da notícia, quem recebe o conteúdo acaba convencido daquela informação e aplica em seu dia a dia mecanismos de defesa caso se ache amaçado. "O coenunciador incorpora, assimila um conjunto de esquemas que correspondem à maneira específica de relacionar-se com o mundo, habitando seu próprio corpo" (MAINGUENEAU apud AMOSSY, 2014, p. 73). Mesmo que não saiba nada sobre o enunciador, o fato de um texto pertencer a determinado gênero de

\footnotetext{
${ }^{1}$ Embora tratemos de leitores, entendemos receptores de informação de forma geral: leitores, ouvintes, espectadores, internautas. Maingueneau chama de coenunciadores.
} 
discurso (ou a um posicionamento ideológico) induz "expectativas em matéria de ethos" (MAINGUENEAU, in AMOSSY, 2014, p. 72).

Para o autor, o enunciador confere a si próprio e ao seu destinatário um status para a legitimação do seu saber. Assim, o ethos discursivo está ligado à legitimidade do locutor. Maingueneau relaciona o termo também à noção de "tom", tanto no que se refere à fala quanto à escrita, pois qualquer discurso escrito possui uma vocalidade específica. Esses “tons” estão associados “a uma caracterização do corpo enunciador, a um 'fiador', construído pelo destinatário a partir de índices liberados na enunciação” (MAINGUENEAU apud MOTTA; SALGADO, 2015). O jornalista, ao reportar ao público notícias, comporta-se como esse "fiador". A introdução desse conceito compõe a reformulação teórica do autor que menciona ter deformado o ethos por se distanciar da prática oratória e privilegiar o texto escrito (que tem a vocalidade manifestada em múltiplos "tons"). O fiador compreende uma representação imaginada pelo leitor a partir de pistas textuais. Assim, recebe caráter ou traços psicológicos e corporalidade que se sustentam em um conjunto partilhado ou cristalizado de representações sociais que são passíveis de avaliação coletiva. Maingueneau (2015) considera a enunciação apoiada em estereótipos culturais, reforçando e transformando os dados difundidos por diferentes linguagens.

Para Michel Foucault (2014), na sociedade, sabe-se que qualquer um não pode falar de qualquer coisa. Trata-se do conceito de formação discursiva, o que pode e deve ser dito a partir de uma posição dada em certa conjuntura. Em toda sociedade "a produção do discurso é ao mesmo tempo controlada, selecionada, organizada e redistribuída por certo número de procedimentos que têm por função conjurar seus poderes e perigos" (FOUCAULT, 2014, p. 8). As "práticas discursivas" geram "relações de saber" que, por sua vez, determinam as "relações de poder". Trata-se do modo como a sociedade se estrutura a partir da linguagem e do saber. Os jornais, em seus formatos físicos e digitais, têm a legitimidade de representação. Assim, seus discursos tornam-se confiáveis. Mas em função da repetição de determinados conteúdos, tornam esses discursos exagerados e acabam por aproximar seus leitores à violência, aos ideais (de quem?) de beleza, aos fracassos sociais. 


\section{Medo compartilhado}

Em março de 2015, nas redes sociais Facebook e Instragram, encontravam-se pessoas comentando que em farmácias de Campinas, cidade do interior do estado de São Paulo, um determinado tipo de repelente de insetos que, "segundo consta", diziam os comentários, "é o único eficaz na prevenção de picadas do mosquito da dengue", estava em falta. Observou-se, também, que havia quem estocasse o produto em quantidades muito superiores às necessidades imediatas de suas famílias, justamente porque já começava a escassear no mercado. Campinas enfrentava a maior epidemia de dengue registrada até aquele momento ${ }^{2}$. Uma foto no Instagram demonstrava que uma família adquirira 40 unidades do referido repelente. No texto que acompanhava a foto, a autora informava que, devido ao grande número de casos de dengue registrados na cidade, não podia mais viver sem aquilo. Observou-se que eram 40 embalagens do produto para uma família de quatro pessoas (informação obtida também no Instagram). Verifica-se no exemplo o medo que levou essa família, com boa condição socioeconômica, a estocar um produto para defender a saúde. A dengue se aproximava, então, já que a prevenção pregada há anos em campanhas do Ministério da Saúde não dá conta de acabar com a doença, pois depende de todos seguirem as orientações para que o mosquito não se prolifere, o ideal era a precaução. Mas seriam mesmo necessários tantos repelentes de uma só vez?

Notícias publicadas em veículos de comunicação do país indicavam que o aumento do número de casos de dengue se deu devido à escassez de água registrada em 2014/2015. A seca e a necessidade de se impor um rodízio no abastecimento das cidades $^{3}$, onde os níveis dos reservatórios caíam cada vez mais, provocaram a população ao armazenamento de água, principal causa da proliferação do mosquito que provoca a doença.

\footnotetext{
2 "O número de casos de dengue no país este ano, até o dia 28 de março, aumentou $\mathbf{2 4 0 , 1 \%}$ em relação ao mesmo período do ano passado. Até 28 de março, foram registrados 460,5 mil casos, contra 135,3 mil registrados no primeiro trimestre de 2014, conforme balanço divulgado hoje (13) pelo Ministério da Saúde." (LEAL, Aline. Agência Brasil, em 13/04/2015. Publicado por Brasil Post. Disponível em: <http://www.brasilpost.com.br/2015/04/13/dengue-brasil-aumento_n_7058274.html>. Acesso em 17 maio 2015).

${ }^{3}$ ESTADÃO Conteúdo. Na estação seca do ano, cidades de São Paulo voltam a racionar por risco de falta d'água. Publicado por Brasil Post, em 09 abr. 2015. Disponível em: <http://www.brasilpost.com.br/2015/04/09/cidades-voltam-racionamento_n_7028380.html>. Acesso em: 17 maio 2015.
} 
O número de casos de dengue nas quatro primeiras semanas do ano aumentou 57,2\% entre 2014 e 2015, saltando de 26.017 para 40.916 em todo o Brasil. Os dados foram divulgados neste sábado (7) pelo ministro da Saúde, Arthur Chioro. Entre outros motivos, o ministro atribui a expansão da doença à crise hídrica, que faz muitas pessoas estocarem água em casa (LEAL, 2015b, grifos no original) ${ }^{4}$.

Aliás, o armazenamento de água também provocou a falta de outro produto: caixas d'água. Reportagem da Revista Época, assinada por Marina Ribeiro, em 05 de fevereiro de 2015, com o título $A$ escassez de caixas d'água em São Paulo, informa que o dono de uma loja de materiais de construção de bairro na capital paulista disse ter vendido em uma semana maior quantidade de caixas d'água do que no ano anterior inteiro. A situação se repetia em quase todos os estabelecimentos do setor: “'Está em falta'; 'Só tem por encomenda'; 'O prazo de entrega é de 30 dias', são algumas das frases que interessados em comprar caixa d'água ouvem em São Paulo. Nas grandes lojas de material de construção os produtos se tornaram mais escassos do que a água" (RIBEIRO, 2015) ${ }^{5}$.

Esses episódios nos remetem ao ano de 2009, quando o medicamento Tamiflu chegou a ser adquirido no exterior, por consumidores que podiam pagar caro por uma caixa do remédio com dez cápsulas, porque era o antiviral mais eficiente no tratamento da Gripe A - H1N1 - e estava em falta no mercado farmacêutico nacional. Quem adquiria o produto não estava necessariamente com a gripe, mas com medo de contrair o vírus e, caso necessário, ficar sem o medicamento. Assim, era conveniente pagar caro por um medicamento, mesmo - e preferencialmente - que não fosse utilizado. A Gripe A foi considerada uma pandemia e, segundo dados da Organização Mundial da Saúde, causou mais mortes em todo o mundo do que o calculado inicialmente. "Segundo os registros oficiais, com casos confirmados em laboratórios, a 'gripe suína', como ficou conhecida, vitimou cerca de 18,5 mil pessoas entre abril de 2009 e agosto de 2010. Já o novo es-

\footnotetext{
${ }^{4}$ LEAL, Aline. Novos hábitos resultantes da falta de água contribuem com explosão de casos da dengue no Brasil em janeiro de 2015. AGÊNCIA BRASIL. Publicado por Brasil Post, em 07 fev. 2015. Disponível em: <http://www.brasilpost.com.br/2015/02/07/dengue-falta-de-agua_n_6635594.html>. Acesso em: 17 maio 2015.

${ }^{5}$ RIBEIRO, Mariana. A escassez de caixas d'água em São Paulo. ÉPOCA: São Paulo, em 05 fev. 2015. Disponível em: <http://epoca.globo.com/colunas-e-blogs/blog-do-planeta/noticia/2015/02/ bescassez-de-caixas-daguab-em-sao-paulo.html>. Acesso em: 17 maio 2015.
} 
tudo estima que esse número esteja entre 151,7 mil e 575,4 mil" (AFP, em G1, 2012). Na época, diariamente havia reportagens a respeito do assunto, evidenciando o número de vítimas fatais da doença.

O medo que se tem de situações "que se ficou sabendo" é frequente, principalmente se esse "ficar sabendo" foi por meio de um discurso legitimado pela imprensa. Naturalmente, a cobertura jornalística exige o acompanhamento dos fatos de interesse público. A falta de água, o aumento no número de casos de dengue, a crise no comércio... São assuntos noticiáveis. A notícia é oportuna, assistemática, perecível, relata eventos incomuns (PARK apud McQUAIL, 2013 , p. 354). Não se questiona o valor-notícia dos casos mencionados. Ao apresentarem informações novas, conflitos e estarem apoiadas em números e estatísticas (MARCONDES FILHO, 2009, p. 274), trazem comparações; são relevantes do ponto de vista da aproximação temporal e espacial. São fatos que devem ser divulgados. Isso não significa que não provocarão medo em seus receptores.

Bauman, em Medo Líquido, comenta que o "que tememos é o mal” (2008, p. 74). Mas como definir o que é mal? Há explicações desde punição divina (definição por meio da fé) à consequência de falhas humanas. No Dicionário de Filosofia (ABBAGNANO, 1998), encontra-se que, do ponto de vista filosófico, a variedade de definições a respeito do vocábulo se resume em duas interpretações fundamentais, a noção metafísica do mal e a noção subjetivista do mal. A concepção metafísica "consiste em considerá-lo como o não-ser diante do ser, que é o bem, ou em considerá-lo como uma dualidade do ser, como uma dissensão ou um conflito interno do próprio ser." Já a concepção subjetiva do mal "não o considera realidade ou irrealidade, mas objeto negativo do desejo ou, em geral, do juízo de valores. [...] é simplesmente um des-valor, objeto de um juízo negativo de valor, e implica, portanto, referência à regra ou norma na qual se fundamenta o juízo de valor" (ABBAGNANO, 1998, p. 638-640).

Apesar de não se ter exatamente uma resposta a respeito do mal, atribui-se ao tipo de inequidade que não se compreende ou não se explica de modo satisfatório. "O 'mal' é aquilo que desafia e explode essa inteligibilidade que torna o mundo suportável” (BAUMAN, 2008, p. 74). O autor cita Hannah Arendt e suas conclusões de que o mal é político e histórico, produzido por homens, manifestando-se onde há espaços institucionais para isso. Assim, a invencibilidade do mal provoca um medo genuíno e insustentável. 
Os habitantes do mundo líquido-moderno, acostumados a praticar a arte da vida líquido-moderna, tendem a considerar a fuga do problema como uma aposta melhor do que enfrentá-lo. Ao primeiro sinal do mal, procuram uma passagem dotada de uma porta confiavelmente pesada para trancar depois que a atravessaram. [...] Feita dos vapores do medo, a neblina exala o mal (BAUMAN, 2008, p. 95).

Nicola Abbagnano refere-se a medo ao apresentar conceitos filosóficos de emoção. Citando Aristóteles, II livro da Retórica, menciona que o pensador se refere a medo como "[...] uma dor ou agitação produzida pela perspectiva de um mal futuro, que seja capaz de produzir morte ou dor" (ARISTÓTELES apud ABBAGNANO, 1998, p. 311). Nem todos os males são temidos, só aqueles que ameacem provocar grandes dores e destruições, estejam próximos ou pareçam próximos.

\section{Medo de notícias ou notícias de medo?}

Para o presente texto, foram consideradas inicialmente notícias publicadas no Brasil Post ${ }^{6}$. Foi realizada busca, no próprio portal, por reportagens a respeito da falta de água e da seca. Quando o vocábulo seca foi procurado, apareceram mais de 750 referências de textos publicados no site (período desde a sua fundação, em janeiro de 2014, até aquele momento, maio de 2015). Procurou-se trabalhar com o que Maingueneau (1993) denomina de termos pivô. "A função de uma 'palavra-chave' consiste exatamente em cristalizar maior parte das redes de sentido de um universo textual [...] conformidade notável entre uma polissemia linguística e coerções discursivas” (MAINGUENEAU, 1993, p. 151). Ao ler os títulos dos textos encontrados (reportagens e artigos), observou-se palavras que indicam o "mal" que pode despertar a emoção e, consequentemente, o medo. Foram selecionadas intencionalmente seis deles. A seleção dos títulos - usados neste artigo como exemplos - se deu por amostra não probabilística por julgamento ${ }^{7}$ (grifos nossos):

\footnotetext{
${ }^{6}$ Tais notícias foram discutidas na II Jornada de Jornalismo Digital, ocorrida entre 04 e 06 de maio de 2015, em Curitiba, e que recebeu o apoio do grupo de pesquisa Comunicação e Cultura Ciber - Click. Parte dos estudos do grupo se concentra na edição brasileira do Huffington Post, por isso, a seleção se deu a partir desse portal de notícias

${ }^{7}$ De acordo com Malhotra (2010), na amostragem por julgamento, o pesquisador seleciona elementos da população que julga representativos da população de interesse ou apropriados por algum outro motivo. Neste caso, foram selecionados títulos que indicavam palavras que podem levar ao "mal" apresentado por Bauman (2008). Observa-se, também, que foram desprezadas as
} 
- Na estação seca do ano, cidades de São Paulo voltam a racionar por risco de falta d'água ${ }^{8}$

- Seca continua crítica e 56 cidades do NE podem entrar em colapso hídrico, diz governo ${ }^{9}$

- Sistema Cantareira antes e depois: imagens de satélite mostram situação chocante cho $^{10}$

- Seca faz morador pagar até R\$ 50 mil por poço artesiano ${ }^{11}$

- Falta de água ameaça segurança alimentar no Brasil, alerta chefe da $\mathrm{FAO}^{12}$

- Seca no Cantareira é a pior da série pelo oitavo mês seguido ${ }^{13}$

Propõe-se discutir as palavras, por meio de sinônimos, e expressões destacadas nos títulos selecionados: risco, falta, crítica, colapso, chocante, seca faz, até R \$ 50 mil, ameaça segurança alimentar, alerta, força, é a pior. Sem dúvida, chamam a atenção para o objeto em pauta no texto, considerando os efeitos de sentido, por serem recorrentes, podem "alarmar" os leitores. Risco, por exemplo, indica a possibilidade, previsível, de perigo. O leitor já deve ficar mais atento, porque corre o risco de ficar, no caso do título mencionado, sem água.

reportagens relacionadas à lei seca, que pela busca apareciam no rol de notícias junto às da seca como crise hídrica.

${ }^{8}$ ESTADÃO Conteúdo. Na estação seca do ano, cidades de São Paulo voltam a racionar por risco de falta d'água. Brasil Post: 09 abr. 2015. Disponível em: <http://www.brasilpost.com. br/2015/04/09/cidades-voltam-racionamento_n_7028380.html>. Acesso em: 17 maio 2015.

${ }^{9}$ CASTRO, Grasielle. Seca continua crítica e 56 cidades do NE podem entrar em colapso hídrico, diz governo. Brasil Post: 01 abr. 2015. Disponível em: <http://www.brasilpost.com.br/2015/04/01/ seca-continua-critica_n_6986222.html>. Acesso em: 17 maio 2015.

${ }^{10}$ AGUIAR, Ione. Sistema Cantareira antes e depois: imagens de satélite mostram situação chocante. Brasil Post: 15 out. 2014. Disponível em: <http://www.brasilpost.com.br/2014/10/15/ sistema-cantareira-imagens-de-satelite_n_5992402.html>. Acesso em: 17 maio 2015.

${ }^{11}$ ESTADÃO Conteúdo. Seca faz morador pagar até R\$ 50 mil por poço artesiano. Brasil Post: 16 nov. 2014. Disponível em: <http://www.brasilpost.com.br/2014/11/16/crise-poco-artesiano_n_6166498.html>. Acesso em: 17 maio 2015.

${ }^{12}$ FELLET, João. Falta de água ameaça segurança alimentar no Brasil, alerta chefe da FAO. BBC Brasil, publicado em Brasil Post: 02 fev. 2015. Disponível em: <http://www.brasilpost.com. br/2015/02/02/falta-de-agua-comida_n_6593134.html>. Acesso em: 17 maio 2015.

${ }^{13}$ ESTADÃO Conteúdo. Seca no Cantareira é a pior da série pelo oitavo mês seguido. Brasil Post: 31 ago. 2014. Disponível em: <http://www.brasilpost.com.br/2014/08/31/seca-no-cantareira_n_5743838.html>. Acesso em: 17 maio 2015. 
Quanto à falta de água, um produto essencial à vida, correr o risco de estar privado de água significa estar ameaçado de morte. Falta indica carência, privação. É uma situação assustadora.

A palavra crítica remete a algo desfavorável. No título em questão, o segundo elencado neste texto, há a informação de que a seca continua crítica. Trata-se de um problema ameaçador que permanece negativo e que pode levar a um colapso, à ruína, ao desmoronamento. O colapso hídrico a 56 cidades do Nordeste do país aponta à precariedade de vida na região.

No terceiro título aqui destacado, tem-se a palavra chocante, ou seja indecente, escandaloso. A frase chama a atenção para uma série de fotos de como era o Sistema Cantareira (um dos principais reservatórios que abastecem a capital paulista) e de como ficou após a seca. Essas imagens mostram a "situação chocante", algo que melindra, que revolta.

A seguir, apresenta-se um título que demonstra uma obrigação. "Seca faz morador pagar" indica que a ameaça provoca efeitos, pois a falta de água está obrigando alguém a gastar, então vem a outra expressão que destacamos, até 50 mil reais, por um poço artesiano. A expressão de relação (até) entre limites parece enfatizar o alto custo pago por um poço artesiano. Quem não tem esse dinheiro corre o risco, para fazer referência ao vocábulo já discutido, de minguar pela escassez de água.

Na sequência, outro título assustador. As palavras: ameaça - tem finalidade de amedrontar, advertir, atemorizar -; segurança - proteção, confiança -; alerta - aviso, sinal de preocupação, vigilância. A seca ameaça a segurança alimentar no Brasil, indica o título. Corremos o risco de morrer de sede e de fome. E o aviso é dado por um chefe, uma autoridade, da Organização das Nações Unidas para Alimentação e Agricultura - FAO.

Então, menciona-se um título que, cronologicamente, apareceu antes dos demais discutidos aqui, em agosto de 2014. O destaque coube à palavra pior, um advérbio comparativo irregular justamente de mal. Pior de uma série registrada pelo oitavo mês consecutivo significa que já estava sistematicamente ruim e agravou-se ainda mais. Mas o pior ainda estava por vir, conforme se observa nos títulos anteriores. Ressalta-se que as autoridades públicas não assumiram a crise hídrica antes das eleições de outubro de 2014, atrasando o quanto 
puderam declarações a respeito do assunto em São Paulo. Relação de poder intermediada pela mídia.

A partir desses exemplos, compreende-se porque tantos cidadãos correram às lojas de materiais de construção em busca de caixas d'água para armazenar o produto. Também se entende a sequência de fatos que levou aquela família à atitude exagerada de compra de grande número de repelentes de insetos com medo da dengue. Destacam-se três títulos de reportagens sobre dengue, também selecionados intencionalmente a partir da busca no site do Brasil Post:

- Casos de dengue no Brasil aumentam 162\% em 2015, aponta Ministério da Saúde ${ }^{14}$

- Casos de dengue no Brasil aumentam 240\% no primeiro trimestre do ano ${ }^{15}$

- 'Centro' da dengue no Brasil, SP bate recorde de mortes em ano de epidemia da doença no País ${ }^{16}$

As informações destacadas se apresentam como dados científicos, ou seja, com pouca possibilidade de coenunciadores questionarem a veracidade, submetem os leitores ao aceite do que foi transmitido como verdadeiro. Trata-se da coerção discursiva (MAINGUENEAU, 1993) ou da vontade de verdade (FOUCAULT, 2014, p. 15): “[...] a verdade se deslocou do ato ritualizado, eficaz e justo, de enunciação, para o próprio enunciado: para seu sentido, sua forma, seu objeto, sua relação a sua referência”. Embora textos jornalísticos sigam técnicas narrativas para transmitir informação, a seleção de títulos já leva ao convencimento, à persuasão.

Para complementar e reforçar o estudo, foi realizado um levantamento de notícias sobre a dengue publicadas pelo jornal O Estado de S. Paulo, edição digital (versão impressa), durante o mês de março

\footnotetext{
${ }^{14}$ BALTAZAR, Larissa. Casos de dengue no Brasil aumentam 162\% em 2015, aponta Ministério da Saúde. Brasil Post: 12 mar. 2015. Disponível em: <http://www.brasilpost.com.br/2015/03/12/ mapa-dengue_n_6855832.html >. Acesso em: 20 maio 2015.

${ }^{15}$ LEAL, Aline. Casos de dengue no Brasil aumentam $240 \%$ no primeiro trimestre do ano. Agência Brasil, publicado em Brasil Post: 13 abr. 2015. Disponível em: <http://www.brasilpost.com. br/2015/04/13/dengue-brasil-aumento_n_7058274.html>. Acesso em: 20 maio 2015.

${ }^{16}$ ARAÚJO, Thiago de. 'Centro' da dengue no Brasil, SP bate recorde de mortes em ano de epidemia da doença no País. Brasil Post: 04 maio 2015. Disponível em: <http://www.brasilpost. com.br/2015/05/04/epidemia-dengue-brasil_n_7204178.html>. Acesso em: 20 maio 2015.
} 
de 2015. De $1^{\circ}$ a 31 de março do referido ano, dengue foi tema de notícias veiculadas pelo jornal em 19 dias (em 04, 05, 06, 07, 11, 12, $13,14,15,16,17,18,21,24,25,26,27,30$ e 31 de março são observadas notas, reportagens ou texto de opinião que abordam o assunto). Em cinco ocasiões, no período, o assunto mereceu estar na primeira página do jornal. Observa-se que março é o último mês do verão e, portanto, normalmente há balanços de eventos que movimentam a estação mais quente do ano. Elaborou-se um quadro com os títulos dos textos jornalísticos publicados no período (grifos nossos).

Quadro 1 - Títulos de textos relacionados à dengue,

O Estado de S. Paulo, março 2015.

\begin{tabular}{|c|c|c|}
\hline Data & Título & Página \\
\hline $04 / 03 / 15$ & Dengue pode ter causado mais 3 mortes & A13 \\
\hline $05 / 03 / 15$ & $\begin{array}{l}\text { Mortes suspeitas de dengue vão a } 60 \text { e interior cria } \\
\text { 'hospital de guerra' (título) } \\
\text { Tendas e barracas foram instaladas em um centro de } \\
\text { triagem em Rio Claro; Marília ergueu um polo da } \\
\text { doença anexo à UBS }{ }^{17} \text { (subtítulo) }\end{array}$ & A18 \\
\hline $06 / 03 / 15$ & $\begin{array}{l}\text { Estado já tem } 100 \text { mil casos sob suspeita de dengue } \\
\text { (título) } \\
\text { Pelo menos } 13 \text { cidades do interior paulista decretaram } \\
\text { emergência e duas, Catanduva e Ubirajara, estão em } \\
\text { calamidade pública (subtítulo) }\end{array}$ & A14 \\
\hline 07/03/15 & SP é líder em mortes por dengue no País & $1^{\text {a }}$ página \\
\hline 07/03/15 & $\begin{array}{l}\text { País registra } 2 \text { casos de dengue por minuto. Capital } \\
\text { paulista tem primeira morte (título) } \\
\text { Saúde. Até } 28 \text { de fevereiro, foram } 174.676 \text { pessoas } \\
\text { infectadas, ante } 73.135 \text { no mesmo período de 2014, } \\
\text { alta de } 139 \% \text {. O avanço da doença no Brasil é puxado } \\
\text { pelo aumento de casos observado no Estado de São } \\
\text { Paulo, com } 94.623 \text { registros (acréscimo de } 697 \% \text { ) } \\
\text { (subtítulo) }\end{array}$ & $\begin{array}{c}\text { E1 } \\
\text { (capa } \\
\text { caderno } \\
\text { Metrópole) }\end{array}$ \\
\hline 07/03/15 & $\begin{array}{l}\text { SP tem } 54 \% \text { dos casos de dengue e lidera em mortes } \\
\text { (título) } \\
\text { Até } 28 \text { de fevereiro, Estado registrou crescimento de } \\
697 \% \text { no número de notificações da doença; óbitos } \\
\text { já chegam a } 32 \text { (subtítulo) }\end{array}$ & E2 \\
\hline
\end{tabular}

${ }^{17}$ UBS = Unidade Básica de Saúde 


\begin{tabular}{|c|c|c|}
\hline $11 / 03 / 15$ & Em três dias, dengue mata mais $10 \mathrm{em} \mathrm{SP}$ & A14 \\
\hline $12 / 03 / 15$ & $\begin{array}{l}4 \text { morrem com suspeita de dengue em Sorocaba } \\
\text { (título) } \\
234 \text { casos de dengue já foram confirmados em } \\
\text { Amparo (destaque) }\end{array}$ & A15 \\
\hline $13 / 03 / 15$ & País tem 140 casos de dengue por hora & $1^{\text {a }}$ página \\
\hline $13 / 03 / 15$ & $\begin{array}{l}\text { País tem } 140 \text { casos de dengue/hora, } 2 / 3 \text { no Estado de } \\
\text { SP, que lidera em mortes (título) } \\
\text { Saúde. Brasil registrou, até o dia } 7 \text { deste mês, } 224,1 \\
\text { mil infectados, avanço de } 162 \% \text { em relação ao } \\
\text { mesmo período do ano passado e de } 22 \% \text { em relação } \\
\text { ao boletim da semana passada; a terceira maior } \\
\text { incidência do País é em São Paulo, com } 281 \text { relatos } \\
\text { por } 100 \text { mil habitantes (antetítulo) }\end{array}$ & A16 \\
\hline $14 / 03 / 15$ & $\begin{array}{l}\text { SP lidera rankings de dengue por cidade (título) } \\
\text { Nível é de epidemia em Catanduva, Sorocaba e } \\
\text { Campinas; Trabiju tem } 235 \text { pessoas doentes e } \mathbf{1 4} \text { mil } \\
\text { casos por } \mathbf{1 0 0} \text { mil habitantes (subtítulo) }\end{array}$ & A17 \\
\hline $15 / 03 / 15$ & $\begin{array}{l}\text { Dengue atinge } \mathbf{9 0 \%} \text { das cidades paulistas (título) } \\
\text { Chamada está acompanhada de foto com a seguinte } \\
\text { legenda: Lotada. AMA }{ }^{18} \text { Vila Barbosa, no Limão, } \\
\text { região mais afetada pela dengue na capital: filas } \\
\text { começam na madrugada }\end{array}$ & $1^{\text {a }}$ página \\
\hline $15 / 03 / 15$ & $\begin{array}{l}\text { Dengue já atinge } \mathbf{6 0 4} \text { das } \mathbf{6 4 5} \text { cidades de SP; Estado } \\
\text { se aproxima de epidemia (título) } \\
\text { Saúde. Segundo Ministério, são } 281 \text { notificações } \\
\text { para cada } 100 \text { mil habitantes; em Sorocaba, a média } \\
\text { é de } 700 \text { casos por dia e, até junho, podem chegar a } \\
45 \text { mil no total. Em Catanduva, que contabiliza } 15 \\
\text { mortes, Câmara instaura comissão para apurar surto } \\
\text { (antetítulo) } \\
\text { A reportagem está acompanhada de infográfico que } \\
\text { explica a doença. } \\
\text { Na mesma página, matéria correlata tem como título: } \\
\text { Líder do 'ranking, Trabiju contesta dados do } \\
\text { Ministério }\end{array}$ & A22 \\
\hline
\end{tabular}

${ }^{18}$ AMA = Assistência Médica Ambulatorial 


\begin{tabular}{|c|c|c|}
\hline $15 / 03 / 15$ & $\begin{array}{l}\text { Paciente espera até } 6 \text { horas por consulta em AMA } \\
\text { (título) } \\
\text { Fila em unidade no Limão, bairro mais atingido } \\
\text { da capital, na zona norte, se forma na madrugada; } \\
\text { Prefeitura terá tenda emergencial (subtítulo) }\end{array}$ & A23 \\
\hline $16 / 03 / 15$ & $\begin{array}{l}\text { Casos de dengue afetam turismo no litoral norte } \\
\text { (título) } \\
\text { Cidades registram baixa procura para o feriado; em } \\
\text { estado de calamidade, Caraguatatuba tem a pior } \\
\text { situação, com } 968 \text { doentes e } 1 \text { morte confirmados } \\
\text { (subtítulo) }\end{array}$ & A22 \\
\hline $17 / 03 / 15$ & Saúde registra $2^{\text {a }}$ morte por dengue na cidade de SP & $1^{\text {a }}$ página \\
\hline $17 / 03 / 15$ & $\begin{array}{l}\text { Capital confirma } 2^{\text {a }} \text { morte por dengue (título) } \\
\text { Menino de } 11 \text { anos, morador do Jardim Ângela, } \\
\text { estava internado no Hospital das Clínicas desde o } \\
\text { dia 25; interior registra mais óbitos (subtítulo) }\end{array}$ & A16 \\
\hline $18 / 03 / 15$ & $\begin{array}{l}\text { Em dois meses, um ano (título) } \\
\text { Cerca de um terço dos municípios paulistas registra, } \\
\text { em dois meses, mais casos de dengue do que em } \\
\text { todo o ano de } 2014 \text {. Levantamento do Estado mostra } \\
\text { lista de } 218 \text { cidades com a doença, principalmente } \\
\text { no noroeste e região de Campinas e Sorocaba (foto). } \\
\text { Em } 118 \text { cidades já há epidemia. }\end{array}$ & $1^{\text {a }}$ página \\
\hline $18 / 03 / 15$ & $\begin{array}{l}\text { Em } 1 / 3 \text { do Estado, dengue supera total de casos de } \\
2014 \text { (título) } \\
\text { Em } 118 \text { dessas } 218 \text { cidades críticas já se vive epidemia } \\
\text { da doença; em alguns casos, crescimento no } \text { n }^{\circ} \text { de } \\
\text { registros chega a } 27.000 \% \text { (subtítulo) }\end{array}$ & A17 \\
\hline $21 / 03 / 15$ & $\begin{array}{l}\text { Epidemia. Governador de São Paulo disse que pediria } \\
\text { à Agência Nacional de Vigilância Sanitária (Anvisa) } \\
\text { autorização especial para usar o medicamento, que } \\
\text { ainda está na segunda etapa de estudo; são } 67 \text { óbitos } \\
\text { no Estado, por complicações da doença, só neste ano } \\
\text { (antetítulo) } \\
\text { Alckmin quer liberar vacina da dengue em fase de } \\
\text { teste; capital tem } 3^{\text {a }} \text { morte (título) } \\
\text { Em } 7 \text { cidades paulistas nem existe mosquito (título } \\
\text { de matéria correlata) }\end{array}$ & A22 \\
\hline
\end{tabular}




\begin{tabular}{|c|c|c|}
\hline $24 / 03 / 15$ & $\begin{array}{l}\text { Aval para vacina contra dengue não foi pedido } \\
\text { (título) }\end{array}$ & A14 \\
\hline $25 / 03 / 15$ & $\begin{array}{l}\text { SP reduz verba para plano emergencial de combate } \\
\text { à dengue (título) } \\
\text { Com previsão inicial de } \mathrm{R} \$ 25 \text { milhões, ação estadual } \\
\text { contra focos do mosquito vai custar } \mathrm{R} \$ 10 \text { milhões } \\
\text { (subtítulo) }\end{array}$ & A15 \\
\hline $26 / 03 / 15$ & $\begin{array}{l}\mathrm{MPF}^{19} \text { investiga ações de combate à dengue em } 40 \\
\text { cidades de SP (título) } \\
\text { Foco é na região de Jales; há suspeita de que a } \\
\text { omissão dos órgãos públicos facilitou a proliferação } \\
\text { da doença (subtítulo) }\end{array}$ & A17 \\
\hline $27 / 03 / 15$ & $\begin{array}{l}\text { SP apura } 10 \text { mortes por dengue e usará tendas } \\
\text { (título) } \\
\text { Houve alta de } \mathbf{2 1 4 \%} \text { nos registros; a capital } \\
\text { confirmou } 4.436 \text { casos em dez semanas (subtítulo) }\end{array}$ & A15 \\
\hline $30 / 03 / 15$ & Dengue: em 3 dias, mortes em 7 cidades (título) & A16 \\
\hline $31 / 03 / 15$ & $\begin{array}{l}\text { Limeira tem } 2 \text { mortes com suspeita de dengue } \\
\text { (título) }\end{array}$ & A14 \\
\hline
\end{tabular}

Fonte: A autora, a partir de levantamento de dados com antetítulos, títulos e subtítulos de notícias a respeito de dengue, entre 01 e 31 de março de 2015, publicadas no jornal O Estado de S. Paulo.

Em março de 2015, no jornal em questão, apenas doze dias não houve registro de informações a respeito da dengue, assunto que passa a ser reportado a partir do dia 04 daquele mês, quando se observa uma nota com o título Dengue pode ter causado mais 3 mortes. Destaca-se a fragilidade da informação, pois indica uma possibilidade, portanto algo ainda não confirmado, de que mortes ocorreram em função da dengue. Embora o texto seja impreciso, ameaça, pois indica que há a capacidade de que a causa de três mortes seja a dengue, além do fato de que a expressão "mais 3" demonstra que o assunto já vinha sendo acompanhado pelo jornal. No dia seguinte, 05 de março, o título de reportagem ligado ao tema é: "Mortes suspeitas de dengue vão a 60 e interior cria 'hospital de guerra”". Novamente, indicação de possibilidade, nesse caso a partir da palavra suspeita. Destaca-se que

${ }^{19} \mathrm{MPF}=$ Ministério Público Federal 
de três casos no título do dia anterior, o número aumentou 20 vezes. A expressão "vão a" indica o avanço da doença. O texto está claro, mas não é preciso, pois enfatiza uma suspeição, uma desconfiança. Há fragilidade no argumento desse discurso, por outro lado, mostra que a doença (dengue) tem grande chance de ser a causa da calamidade que gerou a necessidade de se criar no interior do estado de São Paulo um hospital para diagnosticar pacientes com a doença. Em 06 de março, o número de casos suspeitos chega a 100 mil, mas continua impreciso. No dia seguinte, 07 de março, o assunto é notícia de primeira página, o destaque passa a ser maior. $\mathrm{O}$ tom é de luto, de pesar. São Paulo é o estado brasileiro líder em mortes por dengue, mais da metade dos casos (54\%), no país que registra dois casos da doença por minuto. Na capital, registrou-se a primeira morte.

Relacionam-se, agora, termos (e expressões) pivô de títulos entre os dias 11 e 18 de março, período em que houve registro do assunto diariamente: em três dias, dengue mata dez (pessoas); epidemia; 14 mil casos (em cidade e 100 mil pessoas); 90\% das cidades paulistas (604 de 645 cidades); espera até 6 horas (em fila para atendimento); tenda emergencial; afetam; calamidade; pior situação; segunda morte (na capital); "Em dois meses, um ano" (relacionando o número de casos que em 60 dias foi igual ao registrado durante o ano inteiro de 2014). Essas palavras e expressões que ficam em evidência nos títulos reforçam, a partir de uma encenação discursiva (MAINGUENEAU apud MOTTA; SALGADO, 2015), a imagem de calamidade pública, crise na saúde, incapacidade das autoridades sanitárias controlarem a epidemia. Chama a atenção a falta de destaque no dia 15 de março de 2015 aos dados contestados pelo prefeito da cidade de Trabiju apontando que muitos casos dos 14 mil citados na reportagem foram descartados como dengue e que ainda eram mantidos na estatística que indicavam o município como o campeão de incidência da doença. O caráter negativo da informação recebe maior ênfase e é constante na imprensa.

Nos últimos dez dias do mês de março, portanto de 21 a 31, notícias relacionadas a dengue foram apresentadas em sete dias. O tom de catástrofe vai diminuindo, sem deixar de ser ameaçador. Destacam-se no período as expressões: epidemia, vacina (que não teria o aval das autoridades competentes), redução de verba, plano emergencial, suspeita, omissão, proliferação, apuração (de casos suspeitos), 
alta (no número de casos), mortes. O modo de dizer do jornalista nos casos observados mostra uma instância enunciativa assertiva, porém inquestionável, construindo o ethos de um fiador que procura fazer com que o leitor tenha a sua visão de mundo.

No início do mês de março os títulos enfatizavam as suspeitas e possibilidades. Mais para a metade do mês, no dia 17, o título evidencia a polifonia no discurso jornalístico. O relato é na capital do estado, a voz é de uma autoridade (Saúde = Secretaria Municipal de Saúde) que registra (confirma, portanto), a segunda morte por dengue na cidade. O texto jornalístico reúne uma pluralidade de "vozes" (MAINGUENEAU, 2013), são as fontes da informação, os entrevistados, as testemunhas, as autoridades, o repórter, o editor. A cena de enunciação está ligada a um ethos e a uma incorporação discursiva:

[...] o ethos é uma noção discursiva, ele se constrói através do discurso, não é uma "imagem" do locutor exterior a sua fala; o ethos é fundamentalmente um processo interativo de influência sobre o outro; é uma noção fundamentalmente híbrida (sociodiscursiva), um comportamento socialmente avaliado, que não pode ser apreendido fora de uma situação de comunicação precisa, integrada ela mesma numa determinada conjuntura sócio-histórica (MAINGUENEAU apud MOTTA; SALGADO, 2015, p. 17 - grifos do autor).

Malena Contrera, no artigo O Pânico na Mídia, ao comentar se o público gosta mesmo de violência e por isso consome mais esse tipo de informação passada pela mídia, afirma que a produção desse conteúdo por profissionais da área, por exemplo, está justificada em aspectos quantitativos - maiores índices de audiência de programação sensacionalista - quando o problema é qualitativo.

Buscamos desesperados por mais informações todo o tempo porque sentimos que algo nos falta e, principalmente nos grandes centros urbanos globalizados e globalizantes confundimos, hoje, superabundância e saturação informativa com comunicação (CONTRERA, 1999, p. 13).

Embora o tema proposto na discussão da presente análise não seja violência urbana, mas sim a denominada epidemia de dengue que atingiu, principalmente o estado de São Paulo em 2015, podemos relacionar a ênfase dada ao reportar os assuntos ao pensamento de Contrera. Dengue é um assunto presente no cotidiano de brasileiros há décadas. 
A imprensa acompanha em momentos de maior evidência, quando as ocorrências chamam mais a atenção. Convém deixar claro que não se pretende insinuar, neste artigo, que o Jornalismo provoca a dengue ou inventa casos a respeito. Esses são fatos que devem ser noticiados, pois a situação fugiu ao controle. Compactua-se com McQuail (2013, p. 354) quando aponta, a partir de Walter Lippmann e Robert Park, que a "notícia está situada em algum lugar" entre "familiarizar-se" com e "conhecer algo". A notícia serve para orientar e direcionar a atenção. Para tanto, uma condição é a veracidade dos fatos.

Martins (2005, p. 257) comenta que "a linguagem, em termos argumentativos, é intencional e interpretativa. [...] na comunicação persuasiva joga-se, deste modo, o humano tal como o percebemos, contingente e incerto, embora animado de possibilidades". Quem diz que a juventude e a magreza estão entre os principais objetivos femininos (e mais contemporaneamente masculinos, também) são as revistas, por exemplo. Nas capas há modelos com corpos esculturais, jovens lindas, consideradas perfeitas. Chegam a traumatizar quem acha que foge aos padrões estéticos impostos pela sociedade, tanto que aumentam os números de pessoas que recorrem a cirurgias plásticas com finalidades estéticas ${ }^{17}$. Basta observar, ainda, a quantidade de programas reality shows que prometem felicidade ao "transformar" pessoas normais em pessoas lindas. Essas estratégias midiáticas, e os veículos procuram aumentar audiência, tiragem ou "cliques", levam ao medo de envelhecer, de engordar, de ficar à margem social por não corresponder aos padrões do que é belo. Os esforços para integrar quem estava fora das normas de beleza ditadas pela mídia ${ }^{18}$ são reconhecidos, mas ainda ecoa na sociedade que o padrão de beleza é o da mocinha do folhetim das 21 horas ou as garotas predominantes nas propagandas: magras, brancas e jovens. Assim, no imaginário coletivo, quem não atende aos padrões estabelecidos está à margem da sociedade.

\footnotetext{
${ }^{20}$ Relatório de 2013 da International Society of Aesthetic Plastic Surgery com números sobre cirurgia plástica ao redor do mundo, coloca o Brasil em primeiro lugar. Indica que das 23 milhões de cirurgias plásticas, no mundo, em 2012, só no país foram 1.491.721. Informação disponível em: <http://www2.cirurgiaplastica.org.br/de-acordo-com-a-isaps-brasil-lidera-ranking-de-cirurgias-plasticas-no-mundo/>. Acesso em: 26 set. 2015.

${ }^{21}$ Novelas inserem nas tramas personagens com sobrepeso para discutir o assunto; aumentam a divulgação de editoriais de moda plus size; discutem-se temas relacionados ao emagrecimento como preocupação com a saúde, não beleza.
} 


\section{Considerações finais}

As discussões realizadas neste texto apontam que o medo é motivado por situações reais, mas que os sujeitos conhecem por meio da mídia. Mesmo que uma pessoa tenha poucas chances de vivenciar o que tomou conhecimento pela imprensa, por exemplo, associa que seus familiares e amigos também estão expostos ao problema. É um medo imaginário, "de algo difuso, mas que aparece como possibilidade real ao sujeito e ele passa acreditar nisso. É essa possibilidade imaginada como real - geradora de insegurança" (BAIERL, 2008, p. 143). A consideração feita por Baierl reforça a proposta de discutir o medo e a insegurança amplificados pela liquidez midiática. Informações recebidas diariamente pela mídia e reproduzidas e comentadas nas redes sociais refletem os acontecimentos da sociedade, mas também provocam desconfortos. $\mathrm{O}$ cidadão sente-se próximo de situações geograficamente distantes do local em que ele vive. Compactuamos com Mix quando o autor defende a imagem com função de comunicar e seduzir.

Si el imaginario tiene efectos significativos en campos que van de la religión y la política hasta el mercado, es porque nos mueve mediante la seducción simbólica. La imagen no sólo comunica, seduce. Se deja leer cuando se presenta como figuración narrativa, pero opera igualmente utilizando abstracciones, que se hacen símbo$\operatorname{los}^{19}$ (MIX, 2006, p. 93).

Imagens, embora não tenham sido analisadas neste estudo, normalmente acompanham os textos e são empregadas para chamar a atenção, rompendo com a barreira da apatia ou da desatenção em um processo comunicacional. Mas também acabam superdimensionando realidades. Alguns símbolos da violência em determinadas cidades e regiões levam ao sentimento de obrigação de se preservar a propriedade e o corpo, assegurar conforto e segurança a si e aos próximos. Contrera aponta que a mídia acaba provocando uma crise de percepção na sociedade. Talvez tenha sido o caso da aquisição de grande número de repelente de insetos por uma família de quatro

\footnotetext{
${ }^{22}$ Se o imaginário tem efeitos significativos em áreas que vão da religião e da política ao mercado, é porque somos movidos pela sedução simbólica. A imagem não só comunica, seduz. Pode ser lida quando apresentada como uma figuração narrativa, mas também funciona utilizando abstrações que se tornam símbolos. (Tradução nossa).
} 
pessoas que serviu de exemplo neste texto.

Ao perdermos a consciência corporal, perdemos nossa acuidade sensorial, e ao lesarmos os sentidos de proximidade, passamos pelas coisas sem sermos capazes de nos conectarmos a elas. Ora, se nossa percepção está comprometida, e consequentemente nossa competência conectiva também, estamos seriamente comprometidos em nossa capacidade de estabelecermos os vínculos [...] Sem o estabelecimento de vínculos, o próprio sentido da comunicação em si mesma está comprometido (CONTRERA, 1999, p. 13).

O medo "[...] é reduzido ou eliminado por condições que tornam os males menos temíveis ou os fazem parecer inexistentes" (ARISTÓTELES apud ABBAGNANO, 1998, p. 311). A frequência de notícias a respeito do número de casos da doença, a repercussão do assunto nas redes sociais, a observação de que em farmácias da cidade o produto, que seria eficiente contra o mosquito transmissor da dengue, levaram à conclusão, sim, de que a doença estava próxima e que a família deveria estar protegida. Considerando os domínios de interdiscurso de memória, atualidade e antecipação, o cidadão que acompanha na imprensa o desenrolar daquele acontecimento pode sentir-se ameaçado. As comparações constantes com os índices da doença registrados nos anos anteriores despertam a memória; a cobertura diária confirma que o caso, embora presente no cotidiano das cidades há mais de três décadas, é atual; o tom de cobrança para que as autoridades tomem providências (e nesse aspecto salienta-se que nas reportagens a respeito do assunto há apelos para que a população colabore no combate ao mosquito transmissor do vírus) percebe-se a antecipação.

Ao finalizar esse texto, deve-se lembrar que o medo é uma característica dos seres vivos e tem importante função na proteção e na preservação das espécies. O que se discutiu por ora foi o medo social, que Bauman (2008) chama de medo derivado, e que ocorre com os seres humanos ao interiorizarem um mundo mais inseguro, vulnerável, gerando suspeitas exageradas e, muitas vezes, injustificadas. É a presença do medo sem efetivamente uma causa real. Augé (2013a) afirma que tudo o que acontece e é reportado pela imprensa, "mesmo que seja longe", nos diz respeito e, assim, nos "aterroriza como se fosse perto". Para o autor, o sistema de informação acaba criando essa nova forma de medo, mais evasiva e abstrata. 
O fato de ser mais abstrata não significa que não tenha efeitos concretos, produzindo nos indivíduos um terror paralisante. Como acontece com as novas inquietações planetárias, que são a dimensão obscura e ameaçadora da globalização. Dominadas pela ideia de que o que diz respeito a alguns acaba, mais cedo ou mais tarde, envolvendo todos os outros, as catástrofes nucleares, as epidemias, mas também o terrorismo ou as ameaças do sistema financeiro assumem os contornos quase apocalípticos (AUGÉ, 2013a).

Muitos dos medos que atualmente afligem sociedades, para o autor, não são novos, o que os torna diferentes são a maneira de percebê-los. Se antes eram vistos como medos locais, concretos, havia a impressão de que poderiam ser evitados, prevenidos. Mas hoje, de tão emaranhados, repercutidos e, com isso, amplificados, tem-se a impressão de que qualquer intervenção sobre eles é impossível. Aumenta a sensação de impotência.

Esse medo também pode ser provocado intencionalmente. Por isso, deve-se averiguar se há, e quais são, intenções dos produtores do discurso para amedrontarem a sociedade; analisar as questões ideológicas que procuram a instabilidade do sistema político vigente e as questões culturais da crise da existência. Os textos selecionados para discussão eram noticiosos, não foram considerados textos de opinião, embora uma sequência deste estudo possa incluí-los. Convém dar continuidade à reflexão levando-se em conta também comentários, repercussões de episódios e a representatividade dos autores nas redes sociais. Neste artigo, tratou-se da epidemia de dengue, mas ao medo de se contrair o vírus dessa doença, também foram incorporados a Febre Chikungunya e o Zika Vírus, este último ainda mais ameaçador em função da associação aos casos de nascimento de crianças com microcefalia. Em novembro de 2015, a Zika passa a ser destaque na imprensa. Até então, durante o ano, teve poucas referências tendo sido denominada como "prima da dengue". A mídia mundial também passou a reportar o assunto. Essa doença ameaça um grande evento a ser realizado no Brasil, os Jogos Olímpicos Rio 2016. As notícias se repetem com frequência e o tom permanece dramático, os efeitos, no entanto, merecem nova reflexão. 


\section{REFERÊNCIAS}

ABBAGNANO, Nicola. Dicionário de Filosofia. São Paulo: Martins Fontes, 1998.

AFP, G1 Ciência e saúde. Gripe H1N1 em 2009 matou mais que o estimado, diz estudo. Atualizado em 26/06/2012. Disponível em: <http:// g1.globo.com/ciencia-e-saude/noticia/2012/06/gripe-h1n1-em-2009matou-mais-que-o-estimado-diz-estudo.html>. Acesso em: 21 maio 2015.

AGUIAR, Ione. Sistema Cantareira antes e depois: imagens de satélite mostram situação chocante. Brasil Post: 15 out. 2014. Disponível em: $<$ http://www.brasilpost.com.br/2014/10/15/sistema-cantareira-imagensde-satelite_n_5992402.html>.Acesso em: 17 maio. 2015.

AMOSSY, Ruth (org.). Imagens de si no discurso - a construção do ethos. 2 ed. São Paulo: Contexto, 2014.

ARAÚJO, Thiago de. 'Centro' da dengue no Brasil, SP bate recorde de mortes em ano de epidemia da doença no País. Brasil Post: 04 maio 2015. Disponível em: <http://www.brasilpost.com.br/2015/05/04/ epidemia-dengue-brasil_n_7204178.html>. Acesso em: 20 maio 2015.

AUGÉ, Marc. Les nouvelles peurs. Paris: Éditions Payot \& Rivages, 2013.

Contra o medo - entrevista com Marc Augé. Concedida a Fabio Gambaro. Jornal La Repubblica, 28-01-2013(a). Tradução de Moisés Sbardelotto. Disponível em: <http://www.ihu.unisinos.br/ noticias/517266-contra-o-medo-entrevista-com-marc-auge $>$. Acesso em: 23 set. 2015.

BAIERL, Luzia F. Medo social: dilemas cotidianos. Ponto-e-Vírgula, Revista de Ciências Sociais, PUC/SP. São Paulo, v. 1, n. 3, p. 138-151, $1^{\circ}$ semestre 2008. Disponível em: <http://revistas.pucsp.br/index.php/ pontoevirgula/article/view/14246/10438>. Acesso em: 15 maio 2015.

BALTAZAR, Larissa. Casos de dengue no Brasil aumentam 162\% em 2015, aponta Ministério da Saúde. Brasil Post: 12 mar. 2015. Disponível 
em: <http://www.brasilpost.com.br/2015/03/12/mapa-dengue_n_6855832. html>. Acesso em: 20 maio 2015.

BAUMAN, Zygmunt. Medo líquido. Rio de Janeiro: Jorge Zahar Editor, 2008.

BRASIL POST. The Huffington Post associado à Editora Abril. Disponível em: <www.brasilpost.com.br>. Acesso em 02 maio de 2015.

CASTRO, Grasielle. Seca continua crítica e 56 cidades do NE podem entrar em colapso hídrico, diz governo. Brasil Post: 01 abr. 2015. Disponível em: <http://www.brasilpost.com.br/2015/04/01/seca-continuacritica_n_6986222.html>. Acesso em: 17 maio 2015.

CONTRERA, Malena. O pânico na mídia. Violência - uma das manifestações do pânico. Texto apresentado na COMPÓS - Congresso Nacional dos Programas de Comunicação do Brasil, em 1999. Disponível em: <http://www.cisc.org.br/portal/index.php/biblioteca/ viewdownload/8-contrera-malena-segura/30-o-panico-na-midia.html>. Acesso em: 01 jun. 2015.

ESTADÃO Conteúdo. Na estação seca do ano, cidades de São Paulo voltam a racionar por risco de falta d'água. Brasil Post: 09 abr. 2015. Disponível em: <http://www.brasilpost.com.br/2015/04/09/cidadesvoltam-racionamento_n_7028380.html>. Acesso em: 17 maio 2015.

ESTADÃO Conteúdo. Seca faz morador pagar até R $\$ 50$ mil por poço artesiano. Brasil Post: 16 nov. 2014. Disponível em: <http://www. brasilpost.com.br/2014/11/16/crise-poco-artesiano_n_6166498.html>. Acesso em: 17 maio 2015.

ESTADÃO Conteúdo. Seca no Cantareira é a pior da série pelo oitavo mês seguido. Brasil Post: 31 ago. 2014. Disponível em: <http://www.brasilpost. com.br/2014/08/31/seca-no-cantareira_n_5743838.html $>$. Acesso em: 17 maio 2015.

FELLET, João. Falta de água ameaça segurança alimentar no Brasil, alerta chefe da FAO. BBC Brasil, publicado em Brasil Post: 02 fev. 2015. 
Disponível em: $<$ http://www.brasilpost.com.br/2015/02/02/falta-de-aguacomida_n_6593134.html>. Acesso em: 17 maio 2015.

FOUCAULT, Michel. A ordem do discurso: aula inaugural no Collège de France, pronunciada em 2 de dezembro de 1970. 24 ed. São Paulo: Edições Loyola, [1970] 2014.

GLASSNER, Barry. Cultura do medo. São Paulo: Francis, 2003.

LEAL, Aline. Casos de dengue no Brasil aumentam 240\% no primeiro trimestre do ano. Agência Brasil, publicado em Brasil Post: 13 abr. 2015a. Disponível em: <http://www.brasilpost.com.br/2015/04/13/dengue-brasilaumento_n_7058274.html >. Acesso em: 20 maio 2015.

LEAL, Aline. Novos hábitos resultantes da falta de água contribuem com explosão de casos da dengue no Brasil em janeiro de 2015. AGÊNCIA BRASIL. Publicado por Brasil Post, em 07 fev. 2015b. Disponível em: <http://www.brasilpost.com.br/2015/02/07/dengue-falta-deagua_n_6635594.html>. Acesso em: 17 maio 2015.

LYSARDO-DIAS, Dylia. A construção e a desconstrução de estereótipos pela publicidade brasileira. Stockholm review of Latin American studies, n. 2, nov. 2007, p. 25-35.

MAINGUENEAU, Dominique. Novas tendências em análise do discurso. Campinas: Pontes, 1993.

Análise de textos de comunicação. 6 ed. ampliada. São Paulo: Cortez, 2013.

. Ethos, cenografia, incorporação. In: AMOSSY, Ruth (org.). Imagens de si no discurso - a construção do ethos. 2 ed. São Paulo: Contexto, 2014.

A propósito do ethos. In: MOTTA, Ana Raquel; SALGADO, Luciana (orgs.). Ethos discursivo. 2 ed. São Paulo: Contexto, 2015.

MALHOTRA, Naresh K. Pesquisa de marketing: uma orientação 
aplicada. 2 ed. Porto Alegre, RS: Bookman, 2010.

MARCONDES FILHO, Ciro (org). Dicionário da comunicação. São Paulo: Paulus, 2009.

MARTINS, Moisés de Lemos. A verdade e a função da verdade nas Ciências Sociais. Cadernos Noroeste, Vol. 7 (2), 1994, 5·18. Centro Ciências Históricas e Sociais Universidade do Minho, Portugal. Disponível em: <http://repositorium.sdum.uminho.pt/ handle/1822/25385>. Acesso em: 18 mai 2015.

- A actualidade da comunicação persuasiva. Comunicação e

sociedade, vol. 8, 2005, pp. 255-257. Centro de Estudos de Comunicação e Sociedade (CECS), Universidade do Minho. Disponível em: $<$ http:// revistacomsoc.pt/index.php/comsoc/article/view/1196>. Acesso em: 19 mai 2015.

Crise no castelo da cultura: das estrelas para as telas. São Paulo: Annablume, 2011.

MATUCK, Artur. O potencial dialógico da televisão. $2^{\text {a }}$ ed. São Paulo: Annablume, 2000.

McQUAIL, Denis. Teorias da comunicação de massa. Porto Alegre: Penso, 2013.

MIX, Miguel Rojas. El imaginario: civilizacion y cultura del siglo XXI. Buenos Aires (Argentina): Prometeo Libros, 2006.

O ESTADO DE S. PAULO. Edição Digital, versão impressa, dia 02 outubro 2014.

RIBEIRO, Mariana. A escassez de caixas d'água em São Paulo. ÉPOCA: São Paulo, em 05 fev. 2015. Disponível em: <http://epoca.globo.com/ colunas-e-blogs/blog-do-planeta/noticia/2015/02/bescassez-de-caixasdaguab-em-sao-paulo.html>. Acesso em: 17 maio 2015. 